\title{
Electrochemical properties of tungsten oxysulphide thin films as positive electrodes for lithium microbatteries
}

\author{
I MARTIN-LITAS, P VINATIER*, A LEVASSEUR, J C DUPIN ${ }^{\dagger}$ and D GONBEAU ${ }^{\dagger}$ \\ Institut de Chimie de la Matière Condensée de Bordeaux CNRS and Ecole Nationale Supérieure de \\ Chimie et de Physique de Bordeaux, 16, avenue Pey Berland, 33607 Pessac cedex, France \\ ${ }^{\dagger}$ Laboratoire de Physico-Chimie Moléculaire (UMR 5624), Université de Pau et des Pays de l'Adour, 2, avenue du \\ dex 9, France
}

MS received 18 September 2003

\begin{abstract}
Several $\mathrm{WO}_{y} \mathrm{~S}_{z}$ tungsten oxysulphide thin films were tested as positive electrodes for lithium microbatteries. The amorphous $\mathrm{WO}_{1.05} \mathrm{~S}_{2}$ thin film was found very promising. A capacity decrease occurred during the first few cycles, after which the films were able to intercalate reversibly up to 1.1 lithium ion per formula unit under high regime $\left(75 \mu \mathrm{A} / \mathrm{cm}^{2}\right)$. They were tested for 250 charge-discharge cycles, between $3.0 \mathrm{~V}$ and $1.2 \mathrm{~V}$. X-ray photoelectron spectroscopy measurements were performed on different compounds in both intercalated $\left(\mathrm{Li}_{1} \mathrm{WO}_{1 \cdot 05} \mathrm{~S}_{2}, \mathrm{Li}_{2.7} \mathrm{WO}_{1 \cdot 05} \mathrm{~S}_{2}\right.$ and $\left.\mathrm{Li}_{3.8} \mathrm{WO}_{1 \cdot 05} \mathrm{~S}_{2}\right)$ and partially de-intercalated $\left(\mathrm{Li}_{1} \mathrm{WO}_{1.05} \mathrm{~S}_{2}\right)$ states in order to understand the redox processes occurring during the first discharge-charge cycle. The analysis of both the $\mathrm{W} 4 f$ and the $\mathrm{S} 2 p$ peaks has shown that the redox processes involve not only the tungsten atoms but also sulphur atoms. At the beginning of the intercalation, $\mathrm{W}^{6+}$ was first partially reduced into $\mathrm{W}^{5+}$, and then into $\mathrm{W}^{4+}$, but the important stage was the reduction of $\mathrm{W}^{4+}$ into $\mathrm{W}^{0}$. In $\mathrm{W}^{0}$, the electron binding energy was very close to that of metallic tungsten. At the same time, $\mathrm{S}_{2}^{2-}$ ions were partially reduced into $\mathrm{S}^{2-}$ ions. But only the reduction process of tungsten atoms appeared to be totally reversible.
\end{abstract}

Keywords. Lithium microbattery; tungsten oxysulphide; thin film; X-ray photoelectron spectroscopy (XPS); sputtering.

\section{Introduction}

In recent years, there has been a continuous effort towards developing miniaturized electric devices which require low power. This has motivated numerous studies on lithium and lithium-ion solid-state thin film batteries, also called microbatteries. These ultra thin batteries generally consist of $20 \mu \mathrm{m}$ thick active layers and the entire thickness of the device is $<200 \mu \mathrm{m}$ including the packaging. They can be fabricated in any shape and have a huge potential in consumer electronics applications (smart cards, tags...) and implanted medical devices. Research has recently been focused on the improvement of the thin film cathodes and a number of studies on oxides such as $\mathrm{LiMn}_{2} \mathrm{O}_{4}$ (Shokoohi et al 1991; Hwang et al 1994; Liu et al 1999; Park et al 2000), $\mathrm{LiCoO}_{2}$ (Fragnaud et al 1996; Wang et al 1996; Perkins et al 1999; Bates et al 2000; Neudecker et al 2000), $\mathrm{Li}_{x}\left(\mathrm{Mn}_{y} \mathrm{Ni}_{1-y}\right)_{2-x} \mathrm{O}_{2}$ (Neudecker et al 1998), $\mathrm{V}_{2} \mathrm{O}_{5}$ (Bates et al 1994; Jeon et al 2001) or sulphides such as $\mathrm{TiS}_{2}$ have been initiated (Jones and Akridge 1996). These thin films are often annealed after

*Author for correspondence deposition in order to recover crystallinity so that properties similar to those of the bulk materials used in large capacity batteries are obtained. However, for some applications such as direct deposition of the microbattery onto a silicon chip, high temperature treatments are forbidden. Nevertheless, there have been very few studies devoted to the characterization of as-deposited thin films (Shokoohi et al 1992). This has led us to focus our interest on amorphous cathode materials (Meunier et al 1989; Martin et al 1999).

The principal methods used in thin film cathode preparation are sputtering, evaporation and laser ablation. An important advantage of these methods is that they enable preparation of new materials. Since sputtering offers extremely high quenching speeds, new homogeneous amorphous materials can be readily prepared which may not have any crystalline phases of the same composition. On the basis of this approach, we have prepared transition metal oxysulphide thin films using radio-frequency (RF) sputtering and we have tested them as positive electrodes for lithium batteries. Our results obtained with titanium and molybdenum oxysulphide thin films have been promising (Meunier et al 1989; Martin et al 1999). We present in this paper an extensive analysis of electrochemical properties of the $\mathrm{WO}_{y} \mathrm{~S}_{z}$ thin films. The redox reactions 
which occur during lithium intercalation/de-intercalation have been investigated using X-ray photoelectron spectroscopy (XPS).

\section{Experimental}

Tungsten oxysulphide thin films were prepared by reactive RF magnetron sputtering. The target $(5 \mathrm{~cm} \mathrm{dia.)} \mathrm{was}$ obtained by pressing a $2 \mathrm{H}-\mathrm{WS}_{2}$ polycrystalline powder (Cerac, $99.8 \%$ ) under $250 \mathrm{MPa}$ pressure. Argon or an argon-oxygen mixture was used as the discharge gas. The total pressure was $1 \mathrm{~Pa}$ and the oxygen partial pressure was either 0 or ranging from $10^{-4} \mathrm{~Pa}$ to $10^{-2} \mathrm{~Pa}$. To prevent any contamination of the film, the sputtering chamber was designed to open up inside a glove box under dry argon atmosphere. More details on the preparation of thin films by this procedure are given elsewhere (Martin-Litas et al 2002).

For the electrochemical studies, the thin films were deposited for $1 \mathrm{~h}$ duration onto polished stainless steel substrates. They were cycled galvanostatically in a Li/ $\mathrm{LiAsF}_{6}, \mathrm{EMC} 1 \mathrm{M} / \mathrm{WO}_{y} \mathrm{~S}_{z}$ cell. A relaxation of $2 \mathrm{~h}$ was imposed between every discharge and charge. All the samples were washed with acetonitrile after cycling in order to remove the residual liquid electrolyte. The $\mathrm{Li}_{x} \mathrm{WO}_{y} \mathrm{~S}_{z}$ films were then transferred to the XPS spectrometer glove box via airtight containers. Because of the uncertainty in the (very low) weights of the thin films $(\sim 0.30 \pm 0.06 \mathrm{mg})$, the amount of intercalated lithium ions could not be ascertained accurately $(\Delta x / x \sim$ $25 \%$ ). A thin film at a given stage of the cycling is characterized both by the voltage and the corresponding value of $x$.

The XPS analyses were performed using a Surface Science Instruments spectrometer (model 301) with a focused monochromatized AlK $\alpha$ radiation $(1486.6 \mathrm{eV})$. The residual pressure inside the analysis chamber was in the $10^{-8} \mathrm{~Pa}$ range. The diameter of the irradiated area was $600 \mu \mathrm{m}$. The spectrometer was calibrated using the photoemission lines of $\mathrm{Au}\left(\mathrm{Au} 4 f_{7 / 2}=83.9 \mathrm{eV}\right.$, with reference to the Fermi level) and $\mathrm{Cu}\left(\mathrm{Cu} 2 p_{3 / 2}=932.5 \mathrm{eV}\right)$; for the Au $4 f_{7 / 2}$ line, the full width at half maximum (FWHM) was $0.86 \mathrm{eV}$ under recording conditions. Peaks were recorded with constant pass energy of $50 \mathrm{eV}$. The thin films were found to be sufficiently good conductors to preclude charging effects. The XPS signals were analysed by using a peak synthesis program in which a nonlinear background is assumed. The fitting peaks of the experimental curve are defined by a combination of Gaussian (80\%) and Lorentzian (20\%) distributions. For the whole set of thin films, the curve fits have been obtained using fixed spin-orbit splitting, fixed amplitude and full width at half maximum (FWHM) ratios. Systematic analyses were done before and after mechanical erosion of the sample surface under high vacuum. Several spectra were recorded targeting different locations of the sample surface in order to ensure reproducibility.

\section{Results}

\subsection{Characterization of the $W O_{y} S_{z}$ thin films}

The characterization of the $\mathrm{WO}_{y} \mathrm{~S}_{z}$ thin films using Rutherford backscattering spectroscopy (RBS), scanning electron microscopy (SEM), transmission electron microscopy (TEM), X-ray diffraction (XRD) and XPS is reported elsewhere (Martin-Litas et al 2002). We shall briefly summarize the main results here. The use of different oxygen partial pressures in the discharge gas enables the preparation of a wide range of materials. Without oxygen addition in the sputtering chamber, the composition of the film is $\mathrm{WS}_{2.05}$. When the oxygen partial pressures are maintained at $10^{-4} \mathrm{~Pa}, 10^{-3} \mathrm{~Pa}$ and $6 \times 10^{-3} \mathrm{~Pa}$, the composition of the resulting films were $\mathrm{WO}_{0.3} \mathrm{~S}_{1 \cdot 8}$, $\mathrm{WO}_{1.05} \mathrm{~S}_{2}$ and $\mathrm{WO}_{3 \cdot 0} \mathrm{~S}_{0.2}$, respectively. Compositions determined by XPS were also similar $\left(\mathrm{WO}_{0.5} \mathrm{~S}_{2 \cdot 2}, \mathrm{WO}_{0.9} \mathrm{~S}_{2 \cdot 1}\right.$ and $\mathrm{WO}_{3 \cdot 1} \mathrm{~S}_{0 \cdot 3}$, respectively). XRD and TEM studies confirmed the films to be amorphous, except in the case of oxygen poor compositions, $\mathrm{WS}_{2 \cdot 05}$ and $\mathrm{WO}_{0.4} \mathrm{~S}_{1.96}$. They were found to be nanocrystalline films, and exhibited a strong preferential orientation with their $c$ axes parallel to the substrate.

\subsection{Electrochemical properties}

The thin films described above have been tested as positive electrodes, using the following electrochemical cell configuration: $\mathrm{Li} / \mathrm{LiAsF}_{6}, \mathrm{EMC} 1 \mathrm{M} / \mathrm{WO}_{y} \mathrm{~S}_{z}$. The behaviour of the first two cycles, at $3 \mu \mathrm{A} / \mathrm{cm}^{2}$ and between $3 \mathrm{~V}$ and 1.6 to $1.2 \mathrm{~V}$, are shown in figure 1 as examples. Two common features can be highlighted for the studies on all cells. Firstly, during the first discharge about 2 lithium ions per formula unit are intercalated. Secondly, during the first charge all the lithium ions are not deintercalated. The amount of lithium ions retained in the film depends on its composition. The evolutions of the discharge capacity vs cycle number are compared in figure 2. These data clearly demonstrate that the $\mathrm{WO}_{1.05} \mathrm{~S}_{2}$ thin film is the most promising for battery application. The initial discharge capacity is equal to $57 \mu \mathrm{Ah} / \mathrm{cm}^{2}$. During the first cycles, the capacity progressively decreases down to $37 \mu \mathrm{Ah} / \mathrm{cm}^{2}$ (which corresponds to 1.5 lithium ions reversibly intercalated) and then remains constant.

The $\mathrm{WO}_{1.05} \mathrm{~S}_{2}$ thin film has been tested with different potential windows and different current densities. For amorphous materials, the amount of intercalated lithium ions is not limited by the number of available crystallographic sites as in crystalline materials (Guyomard et al 1997; Liu et al 1998; Denis et al 1999). Therefore, the 

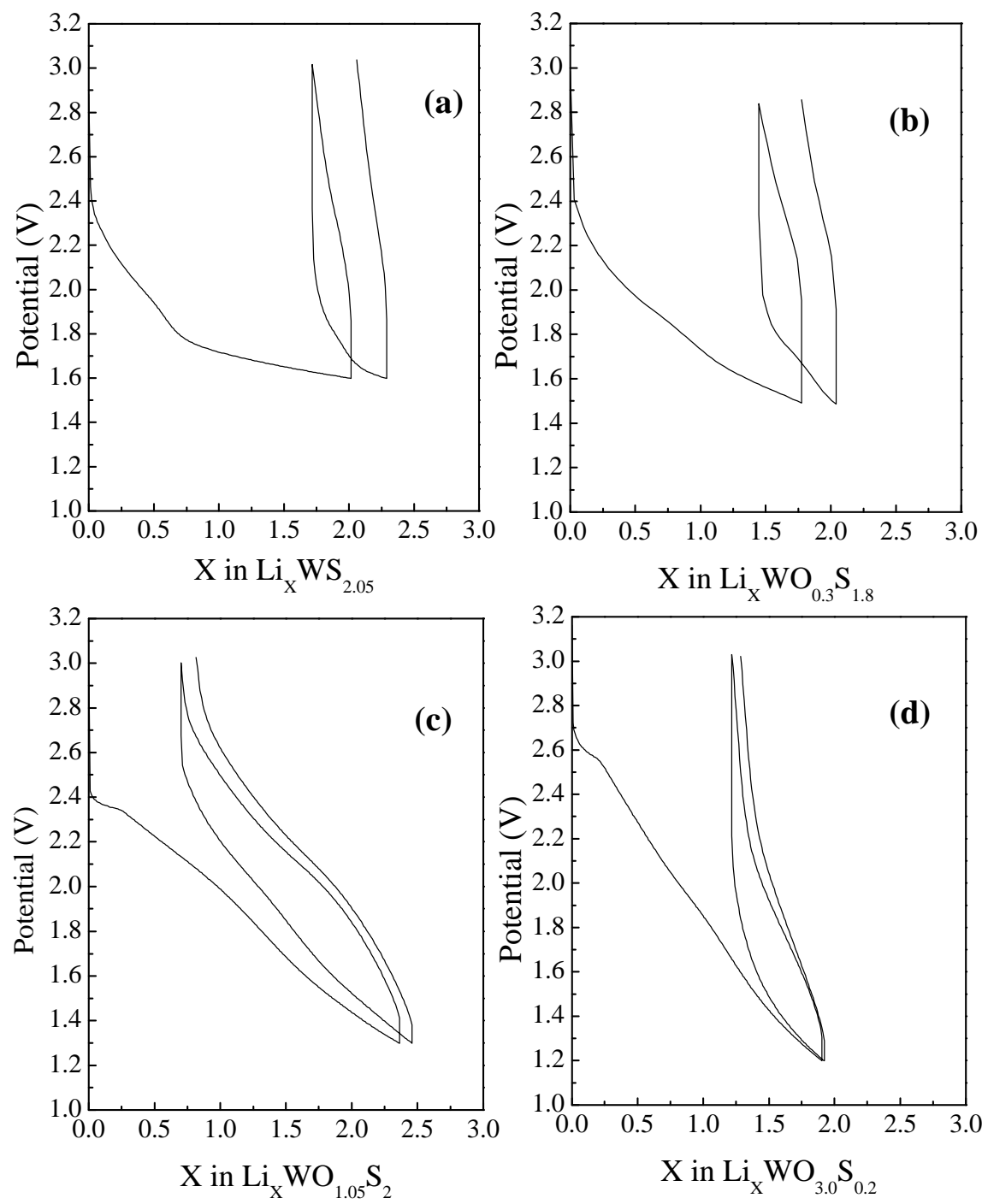

Figure 1. The 2 first cycles for different $\mathrm{Li} / \mathrm{LiAsF}_{6}, \mathrm{EMC} 1 \mathrm{M} / \mathrm{WO}_{y} \mathrm{~S}_{z}$ cells cycled at $3 \mu \mathrm{A} / \mathrm{cm}^{2}$. (a) $\mathrm{WOS}_{2 \cdot 05}$, (b) $\mathrm{WO}_{0 \cdot 3} \mathrm{~S}_{1 \cdot 8}$, (c) $\mathrm{WO}_{1 \cdot 05} \mathrm{~S}_{2}$ and (d) $\mathrm{WO}_{3 \cdot 0} \mathrm{~S}_{0 \cdot 2}$.

end point of the discharge process is somewhat arbitrary and it is possible to increase the capacity by decreasing the cut-off voltage, even down to $0 \mathrm{~V}$. Of course, energy and power are drastically reduced at low potentials, but such studies are of fundamental interest. For the $\mathrm{WO}_{1.05} \mathrm{~S}_{2}$ thin film, 1.85 lithium ions are intercalated at $1.6 \mathrm{~V}, 2.4$ at $1.3 \mathrm{~V}$ and 3.8 at $0.8 \mathrm{~V}$. Besides, an important limitation of disordered structures may be the decreased diffusivity of lithium ions. This results in large polarization at high currents. Figure 3 shows that the capacity of the $\mathrm{WO}_{1.05} \mathrm{~S}_{2}$ thin film cycled between $3.0 \mathrm{~V}$ and $1.2 \mathrm{~V}$ decreases by about one third when the current is increased from $37.5 \mu \mathrm{A} / \mathrm{cm}^{2}$ to $75 \mu \mathrm{A} / \mathrm{cm}^{2}$. In both cases, it becomes very small if the potential window is reduced between $3.0 \mathrm{~V}$ and $1.6 \mathrm{~V}$. Finally, it was noted that $\mathrm{WO}_{1.05} \mathrm{~S}_{2}$ thin film was subjected to 250 chargedischarge cycles, and no capacity loss was observed after the 50th cycle. The results are presented in figure 4 . The evolution of the incremental capacity derivative vs the cell voltage between 150th and 220th cycles shows that the redox processes are completely reversible. In order to have a better understanding of the reversible and irreversible processes involved during the first cycle, an XPS study was carried out.

\subsection{XPS analyses of redox processes}

Systematic XPS analyses were performed at different stages of the charge/discharge cycle (current density, $3 \mu \mathrm{A} / \mathrm{cm}^{2}$ ) of the $\mathrm{WO}_{1.05} \mathrm{~S}_{2}$ thin film. We report here the XPS results obtained on intercalated $(x=1,2 \cdot 7,3 \cdot 8)$ and de-intercalated $(x=1) \mathrm{Li}_{x} \mathrm{WO}_{1 \cdot 05} \mathrm{~S}_{2}$ thin film. Figures 5 and 6 show spectra for the $\mathrm{W} 4 f_{7 / 2-5 / 2}$ and $\mathrm{S} 2 p_{3 / 2-1 / 2}$ peaks, respectively. Table 1 gives the binding energies and relative percentages of different types of tungsten and sulphur atoms. 


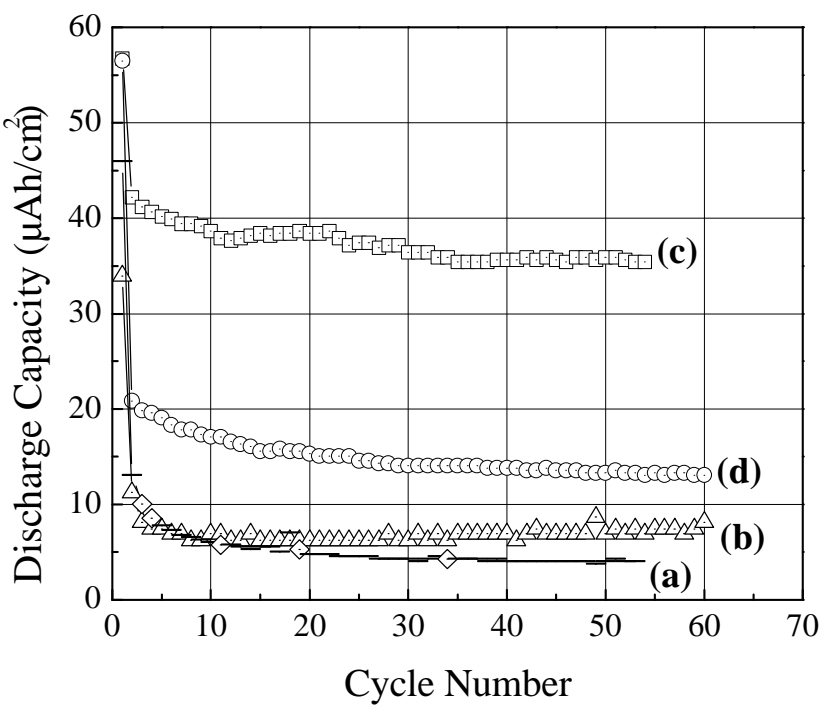

Figure 2. Discharge capacity vs cycle number for different $\mathrm{Li} / \mathrm{LiAsF}_{6}$, EMC $1 \mathrm{M} / \mathrm{WO}_{y} \mathrm{~S}_{z}$ cells cycled at $3 \mu \mathrm{A} / \mathrm{cm}^{2}$. (a) $\mathrm{WOS}_{2 \cdot 05}$, (b) $\mathrm{WO}_{0.3} \mathrm{~S}_{1 \cdot 8}$, (c) $\mathrm{WO}_{1 \cdot 05} \mathrm{~S}_{2}$ and (d) $\mathrm{WO}_{3 \cdot 0} \mathrm{~S}_{0 \cdot 2}$.

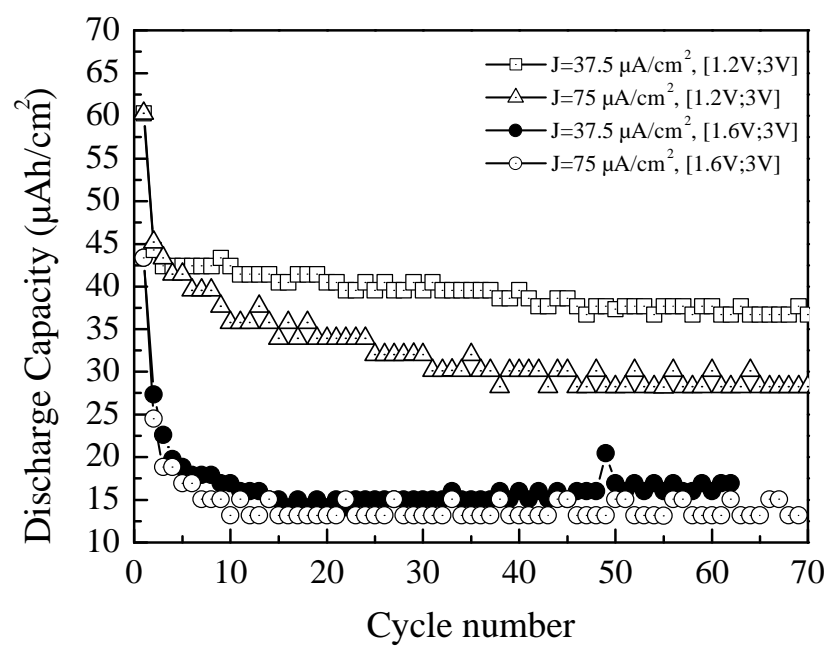

Figure 3. Discharge capacity vs cycle number for $\mathrm{Li} / \mathrm{LiAsF}_{6}$, EMC $1 \mathrm{M} / \mathrm{WO}_{1 \cdot 05} \mathrm{~S}_{2}$ cells, at different potential windows and different current densities.

3.3a $W_{1 \cdot 05} S_{2}$ thin film: In a previous XPS analysis of a different tungsten oxysulphide thin film, it was realized that there were three different environments for the tungsten atoms associated with three distinct doublets A, B and $\mathrm{C}$ in the $\mathrm{W} 4 f$ peak (figure 5a) (Martin-Litas et al 2002). Three different types of sulphur atoms have also been evidenced corresponding to three doublets $D, E$ and F (figure 6a). The proportions of the three environments of tungsten atoms as those of the three sulphur types depend on the composition. The A doublet $(33 \cdot 0-35 \cdot 2 \mathrm{eV})$ is attributed to $\mathrm{W}^{4+}$ ions in a sulphur environment similar to that in polycrystalline $2 \mathrm{H}-\mathrm{WS}_{2}(32 \cdot 8-35 \mathrm{eV})$. In the sul-

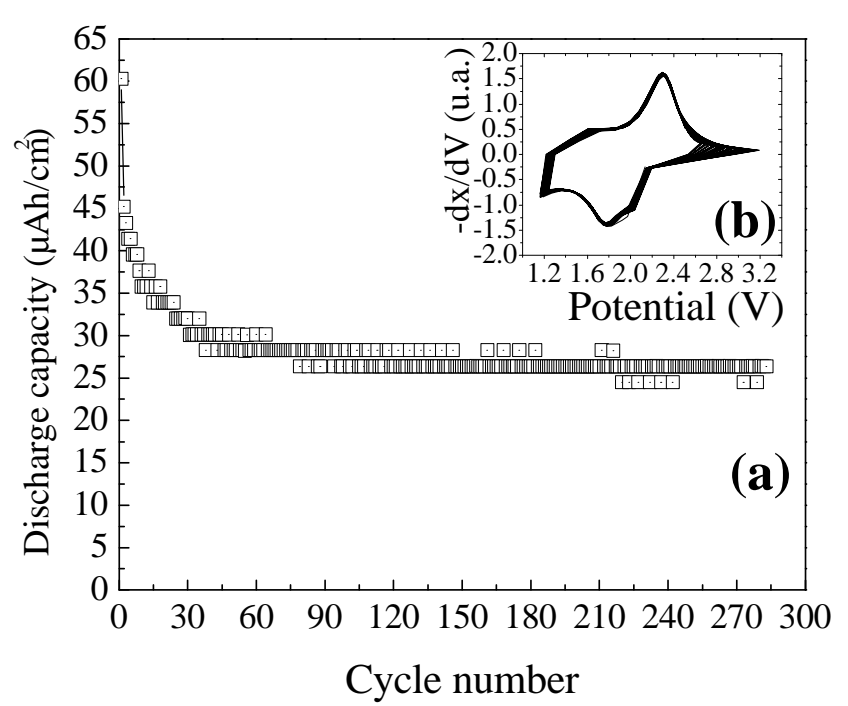

Figure 4. The behaviour of a $\mathrm{Li} / \mathrm{LiAsF}_{6}$, EMC $1 \mathrm{M} / \mathrm{WO}_{1 \cdot 05} \mathrm{~S}_{2}$ cell cycled at $75 \mu \mathrm{A} / \mathrm{cm}^{2}$ between $3.0 \mathrm{~V}$ and $1.2 \mathrm{~V}$. (a) Discharge capacity vs cycle number and (b) incremental capacity derivative vs cell voltage between the 150th and 220th cycles.

phur spectra, the E doublet $(162.4-163.6 \mathrm{eV})$ corresponds similarly to that of $\mathrm{S}^{2-}$ ions in $2 \mathrm{H}-\mathrm{WS}_{2}(162 \cdot 4-163.6 \mathrm{eV})$. The doublet designated as B $(34 \cdot 3-36 \cdot 5 \mathrm{eV})$ in the tungsten spectra is associated with tungsten in $\mathrm{a}+5$ formal oxidation state, since a similar binding energy has been reported for tungsten atoms in sodium bronzes and in $\mathrm{WO}_{3-x}$ (De Angelis and Schiavello 1977; Gehlig et al 1983; Hollinger et al 1985). A further analysis has shown that the tungsten atoms associated with the B doublet are indeed present in a mixed oxygen-sulphur environment: $\mathrm{O}^{2-}$ ions, $\mathrm{S}_{2}^{2-}$ ions ( $\mathrm{F}$ doublet) and $\mathrm{S}^{2-}$ ions (D doublet). These $\mathrm{S}^{2-}$ ions have a lower binding energy than the $\mathrm{S}^{2-}$ ions bonded to a tungsten atom with an exclusive sulphur environment ( $\mathrm{E}$ doublet). The doublet designated as $\mathrm{C}$ (35.7-38 eV) corresponds to $\mathrm{W}^{6+}$ ions, which are similar to those present in $\mathrm{WO}_{3}(35 \cdot 6-37 \cdot 8 \mathrm{eV})$.

3.3b Lithium intercalation in $W_{1.05} S_{2}$ : In the case of intercalated $\mathrm{Li}_{1} \mathrm{WO}_{1.05} \mathrm{~S}_{2}$ thin film, only a small change of the signal shape of the W4 $f$ peak has been observed; this corresponds to a shift of about $0.5 \mathrm{eV}$ towards the high binding energy side, i.e. to an oxidation process (figure $5 b)$. This phenomenon is related to a hydrolysis reaction of the highly reactive intercalated films: variable amounts of $\mathrm{WO}_{3}, 2 \mathrm{H}_{2} \mathrm{O}(36.4-38.6 \mathrm{eV})$ have indeed been detected, corresponding to a fourth doublet at the high-energy side. It has not been possible to avoid this contamination in spite of great care in handling the samples. As a result of this, the relative proportions of $\mathrm{C}$ and $\mathrm{B}$ doublets appear slightly modified (table 1 ). Some partial reduction of $\mathrm{W}^{6+}$ ions into $\mathrm{W}^{5+}$ ions seems to occur. The $\mathrm{S} 2 p$ peak also undergoes changes and the amount of $\mathrm{S}_{2}^{2-}$ disulphide pairs (doublet F) decreases while the proportion of the $\mathrm{S}^{2-}$ ions 
Table 1. Binding energies in $\mathrm{eV}$ of the different tungsten and sulphur atoms, in the following thin films: $\mathrm{WO}_{1 \cdot 05} \mathrm{~S}_{2}$ (initial compound), $\mathrm{Li}_{1} \mathrm{WO}_{1.05} \mathrm{~S}_{2}, \mathrm{Li}_{2.7} \mathrm{WO}_{1.05} \mathrm{~S}_{2}$ and $\mathrm{Li}_{3.8} \mathrm{WO}_{1.05} \mathrm{~S}_{2}$ (obtained at different discharge depths) and $\mathrm{Li}_{1} \mathrm{WO}_{1.05} \mathrm{~S}_{2}$ (obtained after a partial de-intercalation). [Relative atomic percentage in hooks] and (FWHM in eV in brackets).

\begin{tabular}{|c|c|c|c|c|c|c|}
\hline & & \multicolumn{4}{|c|}{ Lithium intercalation } & \multirow{2}{*}{$\frac{\text { Lithium de-intercalation }}{\mathrm{Li}_{1} \mathrm{WO}_{1 \cdot 05} \mathrm{~S}_{2}}$} \\
\hline & & $\mathrm{WO}_{1.05} \mathrm{~S}_{2}$ & $\mathrm{Li}_{1} \mathrm{WO}_{1 \cdot 05} \mathrm{~S}_{2}$ & $\mathrm{Li}_{2 \cdot 7} \mathrm{WO}_{1 \cdot 05} \mathrm{~S}_{2}$ & $\mathrm{Li}_{3.8} \mathrm{WO}_{1 \cdot 05} \mathrm{~S}_{2}$ & \\
\hline \multirow{8}{*}{ W4f } & $\mathrm{WO}_{3}, 2 \mathrm{H}_{2} \mathrm{O}$ & - & $\begin{array}{l}36.6-38.4[16] \\
(1.2)(1.2)\end{array}$ & $\begin{array}{l}36 \cdot 2-38.4[12] \\
(1 \cdot 2)(1 \cdot 2)\end{array}$ & $\begin{array}{l}36 \cdot 4-38 \cdot 6[16] \\
(1 \cdot 2)(1 \cdot 2)\end{array}$ & - \\
\hline & $\mathrm{C}$ & $35 \cdot 7-38 \cdot 0[\mathbf{2 3}]$ & $35 \cdot 7-37 \cdot 9[16]$ & $35 \cdot 7-37 \cdot 9[\mathbf{1 0}]$ & $35 \cdot 9-38 \cdot 1[5]$ & $35 \cdot 5-37 \cdot 6[23]$ \\
\hline & $\left(\mathrm{W}^{6+}\right.$ as in $\left.\mathrm{WO}_{3}\right)$ & $(1 \cdot 3)(1.3)$ & $(1.2)(1.2)$ & $(1.2)(1.2)$ & $(1.2)(1.2)$ & $(1 \cdot 3)(1 \cdot 3)$ \\
\hline & B & $34 \cdot 3-36 \cdot 5[13]$ & $34 \cdot 4-36 \cdot 6[17]$ & $34 \cdot 2-36 \cdot 4[\mathbf{1 1}]$ & $34 \cdot 1-36 \cdot 2[9]$ & $34 \cdot 2-36 \cdot 4[\mathbf{1 6}]$ \\
\hline & $\left(\mathrm{W}^{5+}\right.$ mixed env.) & $(1 \cdot 2)(1 \cdot 2)$ & $(1 \cdot 2)(1 \cdot 2)$ & $(1 \cdot 2)(1 \cdot 2)$ & $(1 \cdot 2)(1 \cdot 2)$ & $(1 \cdot 3)(1 \cdot 3)$ \\
\hline & $\mathrm{A}$ & $33 \cdot 0-35 \cdot 2[64]$ & $33 \cdot 3-35 \cdot 5[\mathbf{5 1}]$ & $32 \cdot 9-35 \cdot 0[44]$ & $32 \cdot 6-34 \cdot 8[16]$ & $32 \cdot 8-35 \cdot 0[\mathbf{6 1}]$ \\
\hline & $\left(\mathrm{W}^{4+}\right.$ as in $\left.\mathrm{WS}_{2}\right)$ & $(1 \cdot 2)(1 \cdot 2)$ & $(1 \cdot 2)(1 \cdot 2)$ & $\begin{array}{l}(1.2)(1.2) \\
31.9-34.0[23]\end{array}$ & $\begin{array}{l}(1.2)(1.2) \\
31.5-33.6[54]\end{array}$ & $(1 \cdot 3)(1 \cdot 3)$ \\
\hline & $\left(\mathrm{W}^{0}\right)$ & - & - & $(1 \cdot 2)(1 \cdot 2)$ & $(1 \cdot 2)(1 \cdot 2)$ & - \\
\hline \multirow{7}{*}{$\mathrm{S} 2 p$} & $\begin{array}{c}\mathrm{F} \\
\left(\mathrm{S}_{2}^{2-}, \text { mixed env. }\right)\end{array}$ & $\begin{array}{l}163 \cdot 3-164 \cdot 5[22] \\
(1 \cdot 1)(1 \cdot 1)\end{array}$ & $\begin{array}{l}163 \cdot 2-164 \cdot 4[14] \\
(1 \cdot 0)(1 \cdot 0)\end{array}$ & $\begin{array}{c}163 \cdot 3-164 \cdot 5[11] \\
(1 \cdot 0)(1 \cdot 0)\end{array}$ & $\begin{array}{l}163 \cdot 2-164 \cdot 3[9] \\
(0 \cdot 9)(0 \cdot 9)\end{array}$ & $\begin{array}{l}163 \cdot 1-164 \cdot 3[9] \\
(1 \cdot 0)(1 \cdot 0)\end{array}$ \\
\hline & $\mathrm{E}$ & $162 \cdot 4-163 \cdot 6[58]$ & $162 \cdot 4-163 \cdot 6[\mathbf{6 1}]$ & $162 \cdot 4-163 \cdot 6[47]$ & $162 \cdot 3-163 \cdot 3$ [27] & $162 \cdot 2-163 \cdot 4[\mathbf{5 8}]$ \\
\hline & $\left(\mathrm{S}^{2-}\right.$ as in $\left.\mathrm{WS}_{2}\right)$ & $(1 \cdot 0)(1 \cdot 0)$ & $(1 \cdot 0)(1 \cdot 0)$ & $(1 \cdot 0)(1 \cdot 0)$ & $(0 \cdot 9)(0.9)$ & $(1 \cdot 0)(1 \cdot 0)$ \\
\hline & D & $161 \cdot 6-162 \cdot 6[20]$ & $161 \cdot 7-162 \cdot 8[25]$ & $161 \cdot 6-162 \cdot 7[35]$ & $161 \cdot 6-162 \cdot 6[49]$ & $161 \cdot 5-162 \cdot 7[33]$ \\
\hline & $\left(\mathrm{S}^{2-}\right.$, mixed env. $)$ & $(1 \cdot 0)(1 \cdot 0)$ & $(1 \cdot 0)(1 \cdot 0)$ & $(1 \cdot 0)(1 \cdot 0)$ & $(0 \cdot 8)(0 \cdot 8)$ & $(1 \cdot 0)(1 \cdot 0)$ \\
\hline & $\underset{\left(\mathrm{S}^{2-} \text { as in } \mathrm{Hi} \text { S }\right)}{ }$ & & & $160 \cdot 8-161 \cdot 8[7]$ & $160 \cdot 9-162 \cdot 0[15]$ & \\
\hline & $\left(\mathrm{S}^{2}\right.$ as in $\mathrm{Li}_{2} \mathrm{~S}$ & - & - & $(1 \cdot 0)(1 \cdot 0)$ & $(0 \cdot 8)(0 \cdot 8)$ & - \\
\hline
\end{tabular}

(doublet D) increases. The $\mathrm{S}_{2}^{2-}$ pairs are partially reduced into $\mathrm{S}^{2-}$ ions (figure $6 \mathrm{~b}$ ).

Upon further intercalation $\left(\mathrm{Li}_{2.7} \mathrm{WO}_{1.05} \mathrm{~S}_{2}\right)$, a significant change of the W4f peak is observed on the lowenergy side, which therefore, reveals a reduction of the tungsten atoms (figure 5c). In order to fit the experimental curve, it was found necessary to add another doublet designated as $\mathrm{G}(31.9-34 \mathrm{eV})$. Its binding energy is very close to the value of the metallic tungsten (31.5$33.7 \mathrm{eV})$. The corresponding tungsten ions are therefore, designated as $\mathrm{W}^{0}$ in the following. With regard to the $\mathrm{S} 2 p$ peak, we note that the signal extends towards the lowenergy side (figure $6 c$ ). This is clearly suggestive of a contribution of the sulphur atoms in the reduction process which occurs during lithium intercalation. A clear increase of the D doublet intensity is observed and with the constraints used, the curve fit implies the introduction of a fourth doublet, designated as $\mathrm{H}(160 \cdot 8-161 \cdot 8 \mathrm{eV})$ (table $1)$. Its binding energy is close to the value of the $S^{2-}$ ions in $\mathrm{Li}_{2} \mathrm{~S}(160 \cdot 7-161.9 \mathrm{eV})$ and characterizes another type of $\mathrm{S}^{2-}$ ions in the film with a more negative charge than the $\mathrm{S}^{2-}$ ions associated with the $\mathrm{E}$ and $\mathrm{D}$ doublets.

When large amounts of lithium ions are intercalated $\left(\mathrm{Li}_{3.8} \mathrm{WO}_{1 \cdot 05} \mathrm{~S}_{2}\right)$, noticeable variations are observed for the $\mathrm{W} 4 f$ peak. The $\mathrm{G}$ doublet ( $\mathrm{W}^{0}$ ions) appears with an enhanced intensity whereas a definite decrease of the intensity of the A doublet ( $\mathrm{W}^{4+}$ ions) is observed (table 1 ). These results show that the main process is the reduction of $\mathrm{W}^{4+}$ ions into $\mathrm{W}^{0}$ ions (figure $5 \mathrm{~d}$ ). Correspondingly, significant changes are observed in the S $2 p$ peak. A shift of the maximum of the signal towards the low-energy side is evident. This corresponds to an increase of the D and $\mathrm{H}$ doublets and a simultaneous decrease of the $\mathrm{E}$ and $\mathrm{F}$ doublets (figure $6 \mathrm{~d}$ ). The results point towards a modification of the electronic density around the sulphur atoms as a consequence of the intercalation of lithium ions.

3.3c Lithium de-intercalation in $\mathrm{WO}_{1.05} \mathrm{~S}_{2}$ : After charging at $3 \mathrm{~V}$, it appears that the redox processes are not completely reversible and only 2.8 lithium ions per formula unit out of 3.8 lithium ions are de-intercalated. For the de-intercalated $\mathrm{Li}_{1} \mathrm{WO}_{1.05} \mathrm{~S}_{2}$ compound, the evolution of the $\mathrm{W} 4 f$ peak (figure $5 \mathrm{e}$ ) shows a complete disappearance of the $\mathrm{G}$ doublet. The $\mathrm{A}, \mathrm{B}$ and $\mathrm{C}$ doublets recover intensities and to similar extent as those for the initial $\mathrm{WO}_{1.05} \mathrm{~S}_{2}$ compound. The results indicate oxidation of $\mathrm{W}^{0}$ ions into $\mathrm{W}^{4+}, \mathrm{W}^{5+}$ and $\mathrm{W}^{6+}$ ions, and therefore a quasireversible redox process for the metal. In the case of the sulphur peak, the $\mathrm{H}$ doublet disappears and the $\mathrm{D}$ doublet intensity decreases compared to the features in the intercalated $\mathrm{Li}_{3.8} \mathrm{WO}_{1.05} \mathrm{~S}_{2}$ thin film. In parallel a significant increase of the $\mathrm{E}$ peak is observed whereas no change is detected for the $\mathrm{F}$ doublet (figure 6e). The reduction of the $\mathrm{S}_{2}^{2-}$ pairs into $\mathrm{S}^{2-}$ ions is therefore not reversible.

It is to be noted that we have also examined the $\mathrm{O} 1 \mathrm{~s}$ peak during lithium intercalation/de-intercalation in order to detect a possible contribution of oxygen. Indeed, in our previous works on transition metal oxides $\left(\mathrm{LiCoO}_{2}\right.$ (Rao et al 2002) and $\mathrm{MO}_{3}$ compounds, $\mathrm{M}=\mathrm{Mo}, \mathrm{W}$ (Dupin et al 2001)), we have evidenced some participation of the oxygen atoms in the redox processes. This 

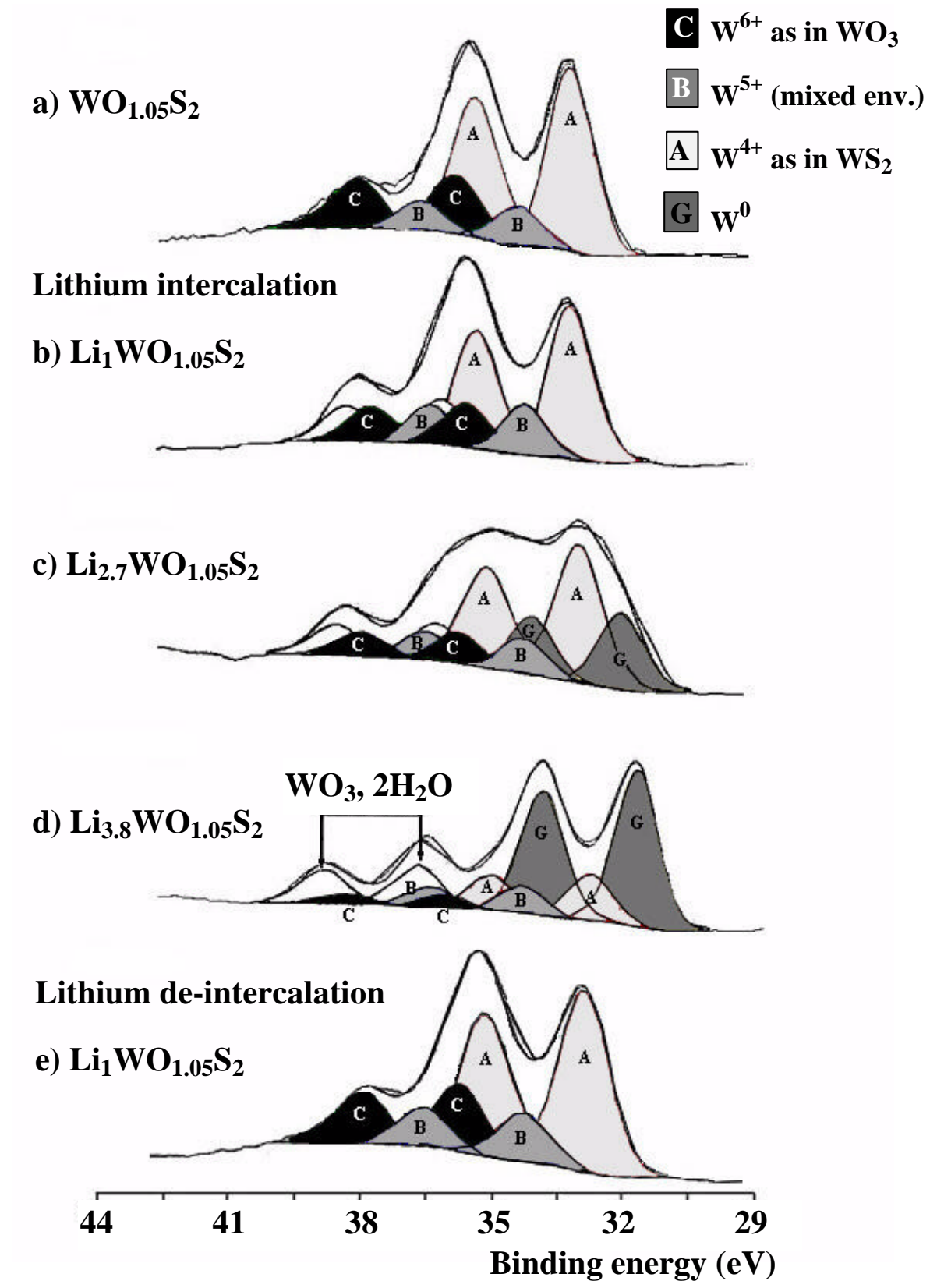

Figure 5. The XPS $\mathrm{W} 4 f$ peak of a $\mathrm{Li}_{x} \mathrm{WO}_{1.05} \mathrm{~S}_{2}$ thin film at various stages of the first cycle. (a) starting material, $x=0,(\mathbf{b}),(\mathbf{c})$ and (d) lithium intercalation, respectively at $x=1,2.7$ and $3 \cdot 8$, and (e) end of the charge, $x=1$.

contribution is suggested in theoretical approaches (Aydinol et al 1997), and indicates possible role of the M-O bond covalency in transition metal oxides. However, in tungsten oxysulphides, we have not observed any contribution of oxygen to be likely because of the presence of sulphur in them.

Another study has been performed on a de-intercalated compound (which was also charged at $3 \mathrm{~V}$ ) obtained after a less deep discharge corresponding to intercalation of 2.7 lithium ions. The analysis of the W $4 f$ peak confirms that the reduction of $\mathrm{W}^{6+}, \mathrm{W}^{5+}$ and $\mathrm{W}^{4+}$ ions into $\mathrm{W}^{0}$ ions is also reversible. And as before, the reduction of $\mathrm{S}_{2}^{2-}$ pairs into $\mathrm{S}^{2-}$ ions is not completely reversible (MartinLitas 2001).

\section{Discussion}

The electrochemical behaviour of the $\mathrm{Li} / / \mathrm{WO}_{y} \mathrm{~S}_{z}$ batteries is quite dependent on the composition of the positive electrode. Nevertheless in all of them very similar redox features have been observed during charge/discharge 


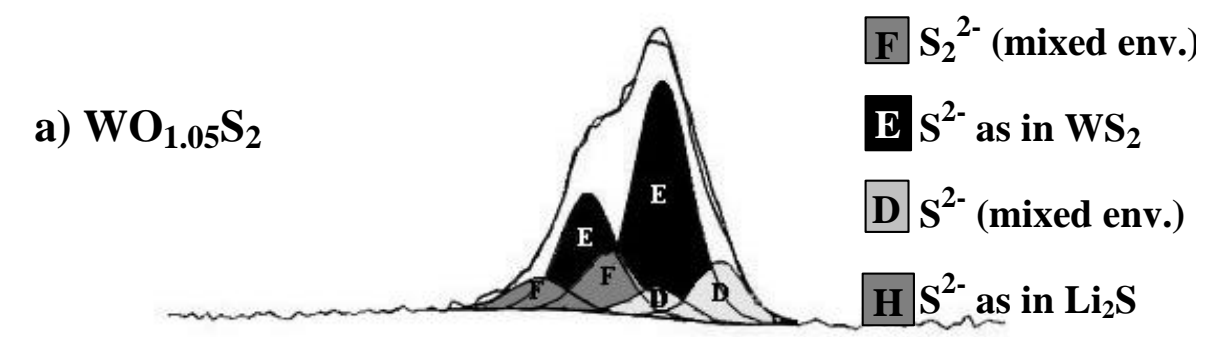

Lithium intercalation

b) $\mathrm{Li}_{1} \mathrm{WO}_{1.05} \mathrm{~S}_{2}$

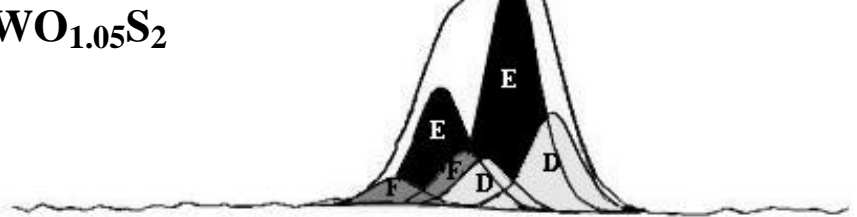

c) $\operatorname{Li}_{2.7} \mathrm{WO}_{1.05} \mathrm{~S}_{2}$

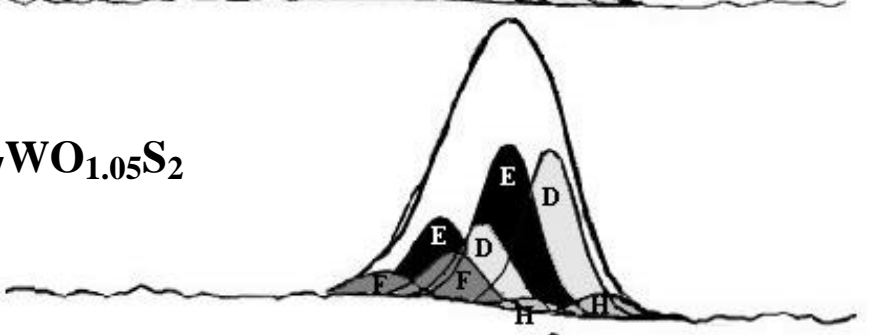

d) $\mathrm{Li}_{3.8} \mathrm{WO}_{1.05} \mathrm{~S}_{2}$

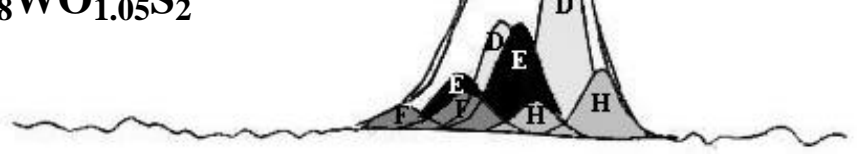

Lithium de-intercalation

e) $\mathrm{Li}_{1} \mathrm{WO}_{1.05} \mathrm{~S}_{2}$

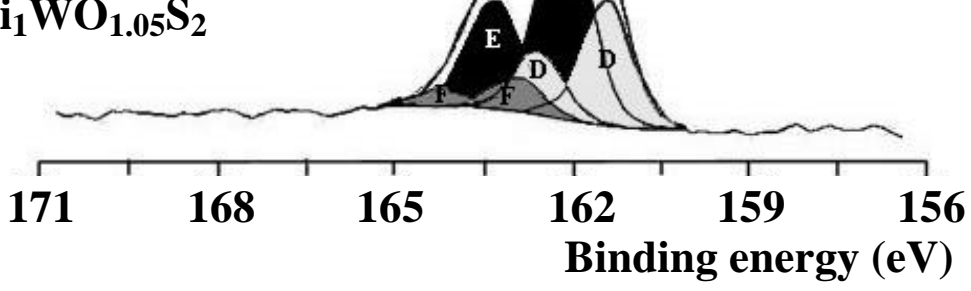

Figure 6. The XPS S2p peak of a $\mathrm{Li}_{x} \mathrm{WO}_{1.05} \mathrm{~S}_{2}$ thin film at various stages of the first cycle. (a) Starting material, $x=0,(\mathbf{b}),(\mathbf{c})$ and (d) lithium intercalation, respectively at $x=1,2.7$ and $3 \cdot 8$ and (e) end of the charge, $x=1$.

process. When the positive electrode films are either amorphous or poorly crystalline, a large amount of lithium ions can be intercalated. Thus, 3.8 lithium ions are intercalated when the $\mathrm{Li} / / \mathrm{WO}_{1.05} \mathrm{~S}_{2}$ cell is discharged at $0.8 \mathrm{~V}$. But 1 lithium ion per formula unit is found to remain irreversibly intercalated when the cell is charged at $3 \mathrm{~V}$. Such phenomena have been previously observed in other amorphous materials also. For example, $\mathrm{InVO}_{4}$,
$2 \cdot 3 \mathrm{H}_{2} \mathrm{O}$ and $\mathrm{FeVO}_{4}, 2 \cdot 7 \mathrm{H}_{2} \mathrm{O}$ can intercalate 15 and 14 lithium ions per formula unit at $0.02 \mathrm{~V}$, respectively but only 8 and 8.5 lithium ions, respectively can be deintercalated (Denis et al 1997). The reduction processes are not completely reversible in these materials also as in the $\mathrm{WO}_{y} \mathrm{~S}_{z}$ thin films. Simultaneously a number of electrons equal to the number of lithium ions is also taken up by the positive electrode materials. One may ask how it 
can accommodate such an amount of electrons. The XPS analysis effectively addresses this question.

When 3.8 lithium ions are intercalated in the $\mathrm{WO}_{1.05} \mathrm{~S}_{2}$ thin films, the corresponding number of electrons causes the reduction of $\mathrm{W}^{6+}, \mathrm{W}^{5+}$ and $\mathrm{W}^{4+}$ ions into $\mathrm{W}^{0}$ ions. The most important process is the partial reduction of $\mathrm{W}^{4+}$ ions into $\mathrm{W}^{0}$ ions. The evolution of cations from a nonzero to a zero oxidation state has been noticed for other materials also (West and Crespi 1995; Chouvin et al 1999; Dedryvere et al 2000; Denis et al 2000; Poizot et al 2000; Grugeon et al 2001). For example, Chouvin et al (1999) have shown by a Mössbauer study on $\mathrm{SnO}$ that during the intercalation of 2 lithium ions, the tin ions are reduced into $\mathrm{Sn}^{0}$ ions. In the same way, Dedryvere et al (2000) have highlighted from their XRD and Mössbauer spectroscopic studies that in the $\mathrm{Li}_{x} \mathrm{Cu}_{0.5+\alpha} \mathrm{In}_{2 \cdot 5-3 \alpha} \mathrm{Sn}_{2 \alpha} \mathrm{S}_{4}$ $(0 \leq \alpha \leq 0.5)$ compounds, two phenomena appear during lithium intercalation. The $\mathrm{Cu}^{\mathrm{I}}$ ions are reduced into $\mathrm{Cu}^{0}$ ions and the $\mathrm{Sn}^{\mathrm{IV}}$ ions are reduced first into $\mathrm{Sn}^{\mathrm{II}}$ ions and then into $\mathrm{Sn}^{0}$ ions, while an amorphous phase containing $\mathrm{Sn}^{0}$ ions is formed. A novel reaction mechanism has recently been reported for cobalt and copper oxides (Poizot et al 2000; Grugeon et al 2001). It highlights a highly reversible redox phenomenon involving the reduction of $\mathrm{CoO}$ or $\mathrm{Cu}_{2} \mathrm{O}$, respectively into cobalt or copper nanograins embedded in a $\mathrm{Li}_{2} \mathrm{O}$ matrix. In our case fully reduced $\mathrm{W}^{0}$ species have been evidenced and the assumption of metal-metal interactions can be made. It is to be noted that we have never noticed major formation of $\mathrm{Li}-\mathrm{S}$ bonds such as present in $\mathrm{Li}_{2} \mathrm{~S}$. This last observation and the possibility of reoxidation of $\mathrm{W}^{0}$ species upon lithium de-intercalation seems to indicate that the tungsten atoms are still in a position to readily interact with the sulphur atoms. XAS studies are in progress to test these hypotheses.

XPS studies have also shown that the lithium intercalation not only involves a modification of the electronic density around the tungsten atoms but also around the sulphur atoms. The participation of anions in the redox processes in $\mathrm{Li}_{x} \mathrm{TiS}_{2}$ has also been reported by $\mathrm{Wu}$ et al (1996) using XAS studies and in $\mathrm{MoO}_{y} \mathrm{~S}_{z}$ amorphous thin films by some of us (Benoist et al 1995). Furthermore, in spite of a wide variation of the cation oxidation state, the partial irreversibility during the first cycle is mainly due to the anions, viz. the $\mathrm{S}_{2}^{2-}$ pairs. During the next cycles, this phenomenon may go on till the complete disappearance of the $\mathrm{S}_{2}^{2-}$ pairs. At this stage, the capacity reaches a stable value. Further experiments are in progress in order to evaluate this proposition.

\section{Conclusions}

The reactive RF magnetron sputtering method using a mixture of argon and oxygen as the discharge gas has enabled preparation of new tungsten oxysulphide thin films.
The novelty of these films is the coexistence of tungsten and sulphur atoms in various formal oxidation states: $\mathrm{W}^{6+}, \mathrm{W}^{5+}$ and $\mathrm{W}^{4+}$ ions, $\mathrm{S}^{2-}$ ions and $\mathrm{S}_{2}^{2-}$ pairs. $\mathrm{WO}_{1 \cdot 05} \mathrm{~S}_{2}$ thin films are the most promising as a material for positive electrode in lithium microbatteries. At $3 \mu \mathrm{A} / \mathrm{cm}^{2}$, it can reversibly intercalate 1.5 lithium ions per formula unit and this capacity is stable over many charge/discharge cycles. Because of a high polarization probably related to the lithium ion diffusion, the capacity is slightly reduced at $75 \mu \mathrm{A} / \mathrm{cm}^{2}$. Nevertheless, the number of reversibly intercalated lithium is still $1 \cdot 1$ atoms per formula unit. An irreversible intercalation is observed during the first cycle. XPS analysis has allowed us to resolve several important issues:

- the $\mathrm{W}^{6+}, \mathrm{W}^{5+}$ and especially $\mathrm{W}^{4+}$ ions are reduced down to the zero oxidation state and this main process is reversible,

- sulphide ions also contribute to the redox process although there is irreversibility in their behaviour.

Further experiments are in progress in order to prepare thin films where the irreversible anionic processes are precluded. With regard to $\mathrm{W}^{0}$ ions, there are two hypotheses which remain to be examined carefully. First, regarding the formation of metallic tungsten aggregates. Second, these tungsten atoms may just reside in their original oxysulphide environment. However, tungstentungsten interactions may still be present due to a possible decrease of the tungsten-tungsten distances. The results presented here seem to favour the second explanation. Nevertheless, a clear-cut experimental proof is still being sought from XAS spectroscopy.

\section{References}

Aydinol M K, Kohan A F, Ceder G, Cho K and Joannopoulos J 1997 Phys. Rev. B56 1354

Bates J B, Gruzalski G R, Dudney N J, Luck C F and Yu X 1994 Solid State Ionics 70-71 619

Bates J B, Dudney N J, Neudecker B, Ueda A and Evans C D 2000 Solid State Ionics 13533

Benoist L, Gonbeau D, Pfister-Guillouzo G, Schmidt E, Meunier G and Levasseur A 1995 Solid State Ionics 7681

Chouvin J, Branci C, Sarradin J, Olivier-Fourcade J, Jumas J C, Simon B and Biensan P 1999 J. Power Sources 81-82 277

De Angelis B A and Schiavello M 1977 J. Solid State Chem. 2167

Dedryvere R, Olivier-Fourcade J, Jumas J C, Denis S and Perez Vicente C 2000 Chem. Mater. 121439

Denis S, Baudrin E, Touboul M and Tarascon J M 1997 J. Electrochem. Soc. 1444099

Denis S, Baudrin E, Orsini F, Ouvrard G, Touboul M and Tarascon J M 1999 J. Power Sources 81-82 79

Denis S, Dedryvere R, Baudrin E, Laruelle S, Touboul M, Olivier-Fourcade J, Jumas J C and Tarascon J M 2000 Chem. Mater. 123733

Dupin J C, Gonbeau D, Martin-Litas I, Vinatier P and Levasseur A 2001 J. Electron Spectrosc. Relat. Phenom. 12055 
Fragnaud P, Brousse T and Schleich D M 1996 J. Power Sources 63187

Gehlig R, Salje E, Carley A F and Roberts M W 1983 J. Solid State Chem. 49318

Grugeon S, Laruelle S, Herrera-Urbina R, Dupont L, Poizot P and Tarascon J M 2001 J. Electrochem. Soc. 148 A285

Guyomard D, Sigala C, Le Gal La Salle A and Piffard Y 1997 J. Power Sources 68692

Hollinger G, Pertosa P, Doumerc J P, Himpsel F J and Reihl B 1985 Phys. Rev. B32 1987

Hwang K H, Lee S H and Joo S K 1994 J. Electrochem. Soc. 1413296

Jeon E J, Shin Y W, Nam S C, Cho W and Yoon Y S $2001 \mathrm{~J}$. Electrochem. Soc. 148 A318

Jones S D and Akridge J R 1996 Solid State Ionics 86-88 1291

Liu W, Huang X, Wang Z, Li H and Chen L 1998 J. Electrochem. Soc. 14559

Liu P, Zhang J G, Turner J A, Tracy C E and Benson D K 1999 J. Electrochem. Soc. 1462001

Martin I, Vinatier P, Levasseur A, Dupin J C and Gonbeau D 1999 J. Power Sources 81-82 306

Martin-Litas I, Vinatier P, Levasseur A, Dupin J C and Gonbeau D 2001 J. Power Sources 97-98 545

Martin-Litas I, Vinatier P, Levasseur A, Dupin J C, Gonbeau D and Weill F 2002 Thin Solid Films 4161
Meunier G, Dormoy R and Levasseur A 1989 Mater. Sci. Eng. B3 19

Neudecker B J, Zuhr R A, Kwak B S, Bates J B and Robertson J D 1998 J. Electrochem. Soc. 145 4149, 4160

Neudecker B J, Dudney N J and Bates J B 2000 J. Electrochem. Soc. 147517

Park Y J, Kim J G, Kim M K, Chung H T and Kim H G 2000 Solid State Ionics 130203

Perkins J D, Bahn C S, Parilla P A, McGraw J M, Fu M L, Duncan M, Yu H and Ginley D S 1999 J. Power Sources 8182675

Poizot P, Laruelle S, Grugeon S, Dupont L and Tarascon J M 2000 Nature 407496

Rao K J, Benqlilou-Moudden J, Couturier G, Vinatier P and Levasseur A 2002 Mater. Res. Bull. 371353

Schmidt E, Meunier G and Levasseur A 1995 Solid State Ionics 76243

Shokoohi F K, Tarascon J M and Wilkens B J 1991 Appl. Phys. Lett. 591260

Shokoohi F K, Tarascon J M, Wilkens B J, Guyomard D and Chang C C 1992 J. Electrochem. Soc. 1391845

Wang B, Bates J B, Hart F X, Sales B C, Zuhr R A and Robertson J D 1996 J. Electrochem. Soc. 1433203

West K and Crespi A M 1995 J. Power Sources 54334

Wu Z Y, Ouvrard G, Lemaux S, Moreau P, Gressier P, Lemoigno F and Rouxel J 1996 Phys. Rev. Lett. 772101 